\title{
LABOR LAW: AGENCY SHOP HELD ILLEGAL FORM OF UNION SEGURITY UNDER TAFT-HARTLEY ACT
}

IN $_{N}$ the absence of state right to work laws, ${ }^{1}$ the Taft-Hartley Act permits employers and labor organizations to enter into collective bargaining agreements requiring union membership as a condition of employment. In states electing to prohibit the union shop, ${ }^{2}$ labor organizations have sought other means of spreading the cost of representation. The agency shop, ${ }^{3}$ conditioning employment upon dues payments rather than union membership, has thus become an important form of union security in those right to work states which have not prohibited this device along with the union shop. ${ }^{4}$ The Court of Appeals for the Sixth Circuit, however, in General Motors Corp. v. $N L R B,{ }^{5}$ has denied unions this means of avoiding right to work statutes by holding the agency shop illegal under federal law, regardless of existing state law.

Subsequent to a determination by the Indiana Appellate Court

${ }^{2}$ States have enacted right to work statutes pursuant to Labor Management Rclations Act (Taft-Hartley Act) $\S 14(\mathrm{~b}), 61$ Stat. I51 (1947), 29 U.S.C. $\$ 164(\mathrm{~b})$ (1958), which provides, "Nothing in this Act shall be construed as authorizing the execution or application of agreements requiring membership in a labor organization as a condition of employment in any State or Territory in which such execution or application is prohibited by State or Territorial Law."

See note 16 infra, for a discussion of the term "membership" as used in this section.

2 At present, twenty states have right to work laws. For a list of these statutory provisions see LAB. REL. REP. (Expeditor) 665.67 (1962).

- The agency shop is a form of union security requiring employees choosing not to join the union to pay fixed sums, usually the equivalent of periodic dues and fees. These sums, in theory, are to cover the costs incurred by the union when acting as bargaining agent for all the employees in the bargaining unit.

This arrangement, also known as the "Rand Formula" gained widespread attention through a 1946 arbitration decision of Justice Rand of the Ontario Supreme Court. In that decision, Justice Rand denied the union's request for a union shop, but permitted the checkoff of an amount equivalent to the union dues from the ivages of all employees, regardless of union membership. Ford Motor Company of Canada, I Lab. Arb. 499 (1946).

The agency shop is currently written into six percent of collective bargaining agreements. 46 I.R.R.M. 18 (1960).

- Twelve of the twenty right to work statutes have specific provisions against compulsory payment of dues and fees to a labor organization. The remaining eight statutes prohibit employers from requiring "membership" in a labor organization as a condition of employment. See LAB. REL REP. (Expeditor) 665.67 (1962). See note 25 infra, for the interpretations courts have given these provisions in determining the legality of agency shop agreements under state right to work laws.

503 F.2d 428 (6th Cir. 1962), cert. granted, 31 U.S.L. WEEK 3169 (U.S. Sept. 4, 1962) (No. 404). 
that the agency shop is valid under Indiana's right to work statute, ${ }^{\circ}$ the United Auto Workers requested General Motors to bargain on an agency shop agreement to cover its employees in that State. When the company refused, contending that such an agreement would violate the Taft-Hartley Act, the union filed an unfair labor practice charge with the National Labor Relations Board. The Board found no unlawful refusal to bargain, holding the agency shop illegal under Taft-Hartley. ${ }^{7}$ Upon reconsideration and after certain changes in its membership, the Board reversed the previous decision and declared the agency shop to be a legal form of union security and thus a mandatory bargaining subject. ${ }^{8}$ On the Company's petition for review, and the Board's cross-petition for enforcement, the Sixth Circuit set aside the Board's reconsidered order, holding the agency shop to be violative of the act. ${ }^{9}$

- Meade Electric Co. v. Hagberg, 129 Ind. App. 631, 159 N.E.2d 408 (1959). The court was dealing with a statute providing that "membership or nonmembership in a labor organization" should not be made a condition of employment. Reasoning that many other states bad right to work legislation when the Indiana law was passed, and that several of these expressly prohibited forced payment of dues and fees to a union, the court found that the legislature intended to legalize the agency shop by not expressly prohibiting such payments. The holding was an affirmation of the trial court's finding. For a criticism of the lower court's reasoning, see Rose, The Agency Shop v. The Right-to-Work Law, 9 LAB. L.J. 579 (1958).

r General Motors Corp., 130 N.L.R.B. 481 (1961). Each member of the majority entered a separate opinion and applied different reasoniug. Member Kimball reasoned that the agency shop is illegal under federal law because non-union employees are not permitted an "economic voice" in the union's bargaining policies. Member Jenkins advanced the theory that compulsory payments by nonmembers are unlawful except where offered as an option to union membership. Chairman Leedom found agency shops illegal in the right to work states regardless of the interpretation state courts give to their statutes on the ground that these are states which have chosen to exercise the 14 (b) privilege of forbidding the conditioning of employment upon "membership" in a labor organization.

With the exception of this decision the NLRB bad consistently held the agency shop to be legal under federal law. American Seating Co., 98 N.L.R.B. 800 (1952); Public Service Co. of Colo., 89 N.L.R.B. 418 (1950); National Elec. Prods. Corp., 3 N.L.R.B. 475 (1937).

${ }^{8}$ General Motors Corp., 133 N.L.R.B. No. 21, 48 L.R.R.M. 1659, reversing 130 N.L.R.B. 480 (1961). Subsequent to the Board's first decision President Kennedy appointed two new members to replace those whose terms had expired, and the Union and the General Counsel filed motions for reconsideration. The Board granted the motions and by a four to one vote vacated the previous decision and held the agency shop to be legal under federal law. The Board reasoned that the union shop proviso to $\$ 8$ (a) (3) merely sets the maximum limits of enforceable union security, permitting lesser forms such as the agency shop.

- The General Motors case presents a dilemma for the parties to agency shop agrcements. An employer and union enforcing such an agreement may be exposed to unfair labor practice charges if other courts adhere to the view of the Sixth Gircuit. On the other hand, the employer refusing to bargain for an agency shop or to enforce such an agreement may be subject to a refusal to bargain charge or a breach of con- 
Determination of the legality of the agency shop under federal law hinges on the interpretation given to section. $8(a)(3)^{10}$ and particularly the term "membership." Section. 8 (a) (3), which generally forbids the employer to condition employment upon union affiliation, contains a proviso permitting bargaining agreements which require union membership after thirty days of employment.11 There are two approaches commonly taken toward defining the term "membership." One, the view of the UAW'2 and the Board, ${ }^{13}$ is that membership merely sets the maximum requirement which may be placed upon the worker, encompassing within its scope lesser requirements such as the payment of dues in an agency shop. The other approach ${ }^{14}$ is that membership as used in this section establishes the exclusive form of union security, the union shop, and proscribes all other forms.

The court chose the strict interpretation of this proviso and found that the disputed section-authorizes "only agreements requiring membership in a labor organization."15 Since the agency shop does not require actual membership, said the court, it is not protected by the act. ${ }^{28}$ No authority was cited in support of this posi-

tract action if other courts agree with the Board and find this a permissible form of union security. The decision thus injects doubt into the numerous contracts containing agency shop agreements and the status of the agency shop in future contract negotiations.

${ }^{10} 61$ Stat. 140 (1947), 29 U.S.C. $\$ 158$ (a) (3) (1958), provides that it shall be an unfair labor practice for an employer "by discrimination in regard to hire or tenure of cmployment or any term or condition of employment to encourage or discourage membership in any labor organization: Provided, That nothing in this Act . . . shali pre. clude an employer from making an agreement with a labor organization ... to require as a condition of employment membership therein. ...."

${ }^{22}$ According to $\$ 8$ (a) (3), membership must be acquired after thirty days of employment, or thirty days after the collective bargaining agreement becomes effective, whichever is later.

12 Brief of UAW as Amicus Curiae, p. 4. ${ }^{13}$ Brief for Appellee, pp. 12-13.

I'The brief of General Motors was unavailable for consideration. However, the Company's position could be ascertained from the other briefs submitted.

${ }^{25}$ General Motors Corp. v. NLRB, 303 F.2d 428, 430 (6th Cir. 1962), cert. granted, 31 U.S.L. WeER 3169 (U.S. Sept. 9, 1962) (No. 404).

${ }^{20}$ Pursuant to the prerogative granted by $\$ 14(b)$ some states have specifically outlawed the agency shop, and others have done so inferentially. Although the question has not been litigated in federal courts, it appears that states have power to prohibit such agreements. Inasmuch as prior to the enactment of $\S 14$ (b) several states had statutes forbidding compulsory payments to unions and Congress lrad knowledge of these statutes, Congress must have intended $\$ 14(\mathrm{~b})$ to grant states authority to outlaw the agency shops.

If states have this power, then the word "membership" in $\$ 14$ (b) must be interpreted to include not only literal membership, but also the compulsory payment of dues and fees. This being so, it appears inconsistent to interpret "membership" in 
tion, except the language of section $8(a)(3)$ itself. ${ }^{17}$ To correctly analyze the rationale of the court and that put forward by the UAW and the NLRB, it is necessary to review the legislative history of the Taft-Hartley Act as well as the relevant case law.

The legislative history of the act indicates a congressional awareness of the need to preserve some form of compulsory unionism as a means of distributing the cost of collective bargaining among all the employees in the bargaining unit. ${ }^{18}$ Congress, by means of the 8 (a) (3) proviso, placed the rights of the majority in a bargaining unit above those of the individual by denying the individual the right to refrain from supporting the union. ${ }^{10}$

The case of Union Starch \& Ref. Co. v. NLRB, ${ }^{20}$ deferring to this congressional purpose, prohibited a union, pursuant to a union shop agreement, from seeking the discharge of an employee who, while refusing actual membership, tendered dues and fees. This decision was cited with approval by the Supreme Court in Radio Officers' Union $v$. $N L R B^{21}$ in which the Court equated union

\$ (8) (a) (3) as Ieferring only to the literal joining of a union, as did the court in the instant case.

For a discussion of this problem see generally, Johannesen, Recent Decisions Concerning the Agency Shop, 40 N.C.L. REv. 603, 612-13 (1962); 62 Gorum. L. REv. 538 (1962).

${ }_{17}$ Brief for Appellee, pp. 22-32, cited extensive legislative history in support of the Board's position. The court declined this aid to interpretation on the ground that it was not for the court "to enjarge the clear language of the statute." 303 F.2d at 430.

${ }^{28}$ As Senator Taft asserted in discussing the proviso to $\$ 8(a)(3)$, "In other words, what we do, in effect, is to say that no one can get a free tide in such a shop. That meets one of the arguments for the union shop. The employee has to pay union dues." 93 Cong. Rec. 3837 (1947).

That Congress had in mind agency shop arrangements when dratfing $\$ \S 8$ (a) (8) and 7 is demonstrated by its awareness of, and reliance on, the arbitration decision of Judge Rand. Senator Taft explained the union security provisions of the act by stating, "IT] ine rule adopted by the committee is substantially the rule now in effect in Canada.... [T] he present rule in Canada is that ... an employee ... must ... . pay dues, even though he does not join the union. If he pays dues without joining the union, he lias the right to be employed." 93 Cong. Rec. 4887 (1947).

${ }^{10}$ Proponents of union security agreements traditionally argue that such agreements provide harmony and internal discipline, as well as preventing employees from benefitting from contracts without cost to themselves. See generally GOLDEN \& RUTTENbURG, The Dynamics of Industrial Democragy 190-230 (1940); Pollitt, Right to Work Law Issues: An Evidentiary Approach, 37 N.C.L. REv. 233 (1959). On the other hand, right to work proponents emphasize the limitations imposed upon employees' freedom of association by union sceurity agreements which make an employee support a union against his desires. See generally Swindler, The Right to Work, A Decade of Development, 36 NEB. L. REV. 276 (1957); 36 GEO. L.J. 198 (1948).

${ }^{20} 186$ F.2d 1008 (7th Cir.), cert. denied, 342 U.S. 815 (1951). Here several employees were willing to pay the equivalent of dues and initiation fees, but because of religious objections would not submit to an oath, a prerequisite of membership.

22347 U.S. 17, 42 (1954). 
membership with the payment of dues alone, and interpreted the congressional intent behind section $8(\mathrm{a})(3)$ as being "to prevent utilization of union security agreements [except] to compel payment of union dues and fees"22 and therefore to eliminate free riders by making them contribute to the union's support. ${ }^{23}$

Thus, the requirement of "membership" as contained in the proviso to section 8 (a) (3) does not mean the literal joining of a union. ${ }^{24}$ Inasmuch as an employee, whether under the agency or union shop, has the same restrictions imposed upon him, namely the payment of dues and fees, the agency shop is nothing more than a clear expression of the maximum form of enforceable union security. ${ }^{25}$

\footnotetext{
$22 I d$ at 41 .

${ }_{23}^{23}$ 'Thus Congress recognized the validity of unions' concern about 'free riders,' . . . and gave the unions the power to contract to meet that problem while withholding from unions the power to "cause the discharge of employees for any other reason." Ibid.

${ }^{3}$ Although supporting case law is limited to the Union Starch and Radio Officers" decisions, it is generally accepted by the commentators that an employee does not have to become an actual member under a union shop agreement, so long as he tenders the equivalent of dues and fees. See Graves, The Agency Shop vs. The "Right to Work," 40 Texas L. Rev. 542, 544 (1962); Rose, The Agency Shop v. The Right to Work Law, 9 LAB. L.J. 579, 579-80 (1958); Toner, The Taft-Hartley Union Shop Docs Not Force Anyone to Join a Union, 6 LAB. L.J. 690 (1955); 2 CCF LAB. L. REP. If 4525,
} at 9550 (1962) ; P-H LAB. REL. II 21,462.3, 22,152.2 (1962).

Section 8(a) (3) prohibits an employer to discriminate against an employee for nonmembership if such membership was denied or terminated for reasons other than delinquency in the payment of dues. Section 8 (b) (2), the reciprocal of $\S 8(a)(3)$ provides that a union cannot cause an employer to discharge an employee for reasons other than the non-payment of dues and fees. For cases disallowing discharge for other reasons see, e.g., NLRB v. Local 815, Teamsters Union, 290 F.2d 99 (2d Cir. 1961) (participation in dual union activities); NLRB v. Local 450, Int'1 Union of Operating Eng'rs, 281 F.2d 313 (5th Cir. 1960), cert. denied, 366 U.S. 909 (1961) (refusal to participate in union activities); NLRB v. National Automotive Fibres, Inc, 277 F.2d 779 (9th Gir. 1960) (non-payment of fines and assessments). See also, Note, 45 GEo. L.J. 250 (1957). These sources indicate that "membership" as used in $\S 8$ (a) (3) does not refer to literal membership, but the payment of fees to the union.

25 Several state courts have recognized this synonymity as evidenced by the decisions considering the legality of the agency shop under right to work statutes drafted only in terms of "membership." All state courts considering the question, with the exception of Indiana, have outlawed the agency shop. The Kansas Supreme Court reached this result by finding that the agency shop constitutes an agreement requiring membership in a labor organization as a condition of employment. The court sup. ported its position by observing that the Supreme Court and lower federal courts have held that the payment of dues and fees is the only enforceable condition of employment under union shop agreements. Such payment being identical with membership, it is therefore illegal in Kansas. Higgins v. Cardinal Mfg. Co., 188 Kan. 11, 360 P.2d 456, cert. denied, 368 U.S. 829 (1961).

In Amalgamated Ass'n of St. Employees v. Las Vegas-Tonopah-Reno Stage Lines, Inc., 202 F. Supp. 726 (D. Nev. 1962), a federal district court interpreted Nevada's right to work law as proscribing agency shop agreements. An Arizona trial court reached the same conclusion under that state's right to work statute. Arizona Flame 
It is submitted that the arguments as to the legality of the agency shop expressed thus far in the dispute, in terms of whether. the proviso to section 8 (a) (3) establishes the exclusive permissible form of union security or the maximum limits, fail to recognize that under no form of permissible union security is an employee required to assume literal membership in a labor organization. The union shop being a protected form of union security under the act, the legality of the agency shop, an identical-form of security, should logically follow. ${ }^{28}$

Moreover, even if courts should find that the agency and union shops are not legally identical, the agency shop should nevertheless be valid under federal law in accordance with the reasoning put forward by the NLRB.27 The Board argued that the union shop is the more coercive form of security in that it demands membership, while the agency shop allows the employee to pay dues without assuming membership. In its desire to afford the employee maximum freedom while concurrently granting the union the right to demand security, Congress, according to the Board, could not have intended to protect the stronger form of union security and at the same time forbid a less demanding form of security. ${ }^{28}$

Restaurant, Inc. v. Baldwin, 26 CCH LAB. CAS. I 68,647 (Ariz. Super. Ct. 1954), aff'd on other grounds, 82 Axiz. 385, 313 P.2d 759 (1957). The Florida Supreme Court, in Schermerhorn v. Local 1625, Retail Clerks, 141 So. $2 d 269$ (Fla. 1962), petition for review granted, 31 U.S.L. WEEK 3169 (U.S. Aug. 24, 1962) (No. 368) held that the agency shop abridged the privilege granted to workers by the state constitution to refrain from joining unions. The constitution provides that employment shall not be conditioned on "membership or nonmembership in any labor union ..." FLA. ConsT., DECLARATION of RrGHTs \& 12. The court found that the agency shop is repugnant to the constitution in that it requires non-union employees to pay fees to the union in order to exercise their constitutional privilege of refusing membership.

For a discussion of state attorney general rulings and the status of the agency shop in each right to work state, see 3 CCH STATE LAB. L. REP. If 49,507 (1962).

${ }^{28}$ When membership is not discriminatorily denied, all employees under an agency shop have the option of becoming members or paying the equivalent of dues and fees; the same options are open to them under a union shop.

In a union shop situation, an employee ineligible for membership as a result of the union's closed membership policies need not pay dues and fees. Assuming an agency shop-closed union situation, if the union could deny membership to employees on discriminatory grounds, while still insisting on support payments as condition of employment, such a union would have a greater form of security than permissible under the union shop since it could maintain its limited membership policies while receiving payments from all employees, including those who lack the option of becoming members.

Since a possible denial of membership was not presented in the instant case, the issue was not decided. For a discussion of the problem see 71 YAIE L.J. 330, 338-41 (1961).

${ }_{27}$ Brief-for Appellee, pp. 11-13.

${ }^{28}$ With the exception of the first General Motors decision, the Board has always 
In conclusion, although the language of a union shop agreement suggests that literal membership is required, it is not. The employee unversed in the intricacies of labor law, however, would seldom be aware of the options available to him. ${ }^{29}$ Therefore, since an agency shop is the form of union security which most clearly defines the relation of the individual employee to the employer and the union, it is the form most consistent with employees' rights as set forth in section 7.30 Congress has decreed that all employees should share in the costs of collective bargaining. The agency shop is clearly in accord with this policy and should be legal under federal law. ${ }^{31}$

held that $\$ 8$ (a) (3) merely sets the maximum limits of permissible union security, and that it thus encompasses and privileges any lesser form of security as well. See, e.g., General Motors Corp., 133 N.I.R.B. No. 21, 48 L.R.R.M. 1659 (1961) (agency shop agreement); American Seating Co., 98 N.L.R.B. 800 (1952) (agency shop agreement);. Public Service Co. of Colo., 89 N.L.R.B. 418 (1950) (agency shop and maintenance-of-membership provisions).

${ }^{2}$ It is recognized that the employee does not have a wide discretion to exercise. Member Leedom, in his dissent to the second Board decision, argues that the agency shop coerces the employee to assume literal membership, by denying to the nonmember certain benefits afforded to members. "For who can say as a verity that a man forced to buy a cake will not eat it." General Motors Corp., 133 N.L.R.B. No. 21, 48 L.R.R.M. 1659, 1664 (1961). Employees with moral or religious objections to unions, horvever, may find it a great solnce to learn that they can avoid becoming members by tendering dues and fees.

so Section 7 provides that employees have the right to refrain from engaging in union activities except as that right may be affected by a collective bargaining agreement requiring membership in a union "as authorized in section 8 (a) (3)."

${ }^{31}$ The justification for the agency shop is that the payments from nonmembers are to be used to defray their share of collective bargaining expenses. There are, however, union expenditures extending beyond the scope of representational activities. Moreover, there are benefits accorded to members to which the nonmembers making identical support payments are not entitled, such as union pension funds and strike relief. To make non-union employees pay for such expenditures would argunbly be to misapply the policy implicit in the union security proviso to the act, as well as to exert substantial coercion upon the employees to assume literal membership.

International Ass'n of Machinists v. Street, 367 U.S. 740 (1961) dealt with the problem of political expenditures by a union operating in a union shop situation. The Court, avoiding the constitutional issue, construed provisions of the Railway Labor Act which permit the union shop as denying the union authority to use an employee's dues, over his objections, for non-bargaining purposes.

This decision was relied on by the North Carolina Supreme Court in Allen v. Southern Ry., 256 N.C. 700, 124 S.E.2d 871 (1962), cert. granted, 83 Sup. Ct. 147 (1962). Here nonmember employees were paying fees to a union expending funds for political purposes. The employees were held entitled to enjoin the enforcement of the union shop agreement until the union could establish what portion of the funds collected from nonmembers are used for purposes related to collective bargaining.

Conceivably, in the Allen case the Court will enlarge on the Street holding and permit only an arrangement whereby payments covering their share of collective bargaining expenses are required of non-union members. Such a system would strictly adhere to the congressional intent that those receiving the benefits of collective bargaining should share in the costs. 